\title{
'Tommy Atkins' mango trees subjected to high density planting in subhumid tropical climate in northeastern Brazil
}

\author{
Carlos Antônio Ferreira de Sousa( ${ }^{(1)}$, Maria Irisvalda Leal Gondim Cavalcanti(2), \\ Lúcio Flavo Lopes Vasconcelos(1), Humberto Umbelino de Sousa(1), \\ Valdenir Queiroz Ribeiro(1) and José Algaci Lopes da Silva(3)
}

\begin{abstract}
(1)Embrapa Meio-Norte, Avenida Duque de Caxias, no 5.650, CEP 64006-220 Teresina, PI, Brazil. E-mail: carlos.sousa@cpamn.embrapa.br, lucio@cpamn.embrapa.br, humberto@cpamn.embrapa.br, valdenir@cpamn.embrapa.br (2)Instituto Federal de Educação, Ciência e Tecnologia do Piauí, Avenida Rio dos Matos, s/no, CEP 64260-000 Piripiri, PI, Brazil. E-mail: iriscavalcanti@ifpi.edu.br (3)Universidade Federal do Piauí, Campus Agrícola do Socopo, Centro de Ciências Agrárias, Departamento de Políticas Agrícolas, CEP 64049-560 Teresina, PI, Brazil. E-mail: algaci@ufpi.edu.br
\end{abstract}

\begin{abstract}
The objective of this work was to evaluate the effects of high density planting on 'Tommy Atkins' mango trees cultivated in subhumid warm tropical climate in northeastern Brazil. Treatments consisted of five spacial arrangements of plants $(8 \times 5 \mathrm{~m}, 7 \times 4 \mathrm{~m}, 6 \times 3 \mathrm{~m}, 5 \times 2 \mathrm{~m}$ and $4 \times 2 \mathrm{~m})$, which resulted in the following plant densities: 250 (control), 357, 555, 1,000 and 1,250 plants per hectare. Plant vegetative and reproductive variables, besides fruit quality parameters, were evaluated at seven and eight years after transplantation to the field. In general, high density planting caused reduction in vegetative and reproductive variables of individual mango trees, but had little influence on fruit quality. Above 555 plants per hectare, a significant decrease was observed in mango tree growth. Furthermore, there were decreases in the percentage of flowering, fruit yield per plant and per area. However, planting density up to 357 plants per hectare, in spite of decreasing plant growth and fruit yield per tree, increases fruit yield per area in 30\% in comparison to the control.
\end{abstract}

Index terms: Mangifera indica, fruit yield, high density orchard.

\section{Mangueiras 'Tommy Atkins' submetidas à alta densidade de plantio em condições de clima tropical subúmido no Nordeste do Brasil}

\begin{abstract}
Resumo - O objetivo deste trabalho foi avaliar os efeitos do adensamento de plantio sobre mangueiras 'Tommy Atkins', sob condições de clima tropical quente subúmido, no Nordeste do Brasil. Os tratamentos consistiram de cinco arranjos espaciais de plantas ( $8 \times 5 \mathrm{~m}, 7 \times 4 \mathrm{~m}, 6 \times 3 \mathrm{~m}, 5 \times 2 \mathrm{~m}$ e $4 \times 2 \mathrm{~m})$, que resultaram nas seguintes densidades de plantio: 250 (controle), 357, 555, 1.000 e 1.250 plantas por hectare. Variáveis vegetativas e reprodutivas das plantas, além de parâmetros de qualidade dos frutos, foram avaliadas no sétimo e no oitavo ano após a implantação do pomar no campo. Em geral, o adensamento populacional causou redução nas dimensões individuais das variáveis vegetativas e reprodutivas das plantas, com pouca influência sobre a qualidade dos frutos. A partir de 555 plantas por hectare, observou-se diminuição significativa do crescimento das plantas de manga. Além disso, houve redução da percentagem de florescimento, da produção de frutos por planta e por área. Entretanto, o adensamento até 357 plantas por hectare, apesar de reduzir o crescimento das plantas e a produção de frutos por planta, aumenta em $30 \%$ a produção de frutos por área, em comparação ao controle.
\end{abstract}

Termos para indexação: Mangifera indica, produção de frutos, pomar adensado.

\section{Introduction}

Mango tree (Mangifera indica L.) is a major tropical fruit species cultivated in Brazil. In 2010, Brazilian production reached 1,197,694 tons of fruit in an area of approximately 75,416 hectares, generating about US\$ 334 million (Instituto Brasileiro de Geografia e Estatística, 2011). Considering both income and exported volume, mango occupied the third place in the segment of fresh fruit, with revenues of US\$ 119,929 million and 124,694 tons of fruit, respectively (Anuário brasileiro da fruticultura, 2011).
More than $90 \%$ of mango exported by Brazil is produced in the São Francisco river valley (Anuário brasileiro da fruticultura, 2011), in the semiarid area of the Northeast region, in which orchards are dominated by the Tommy Atkins cultivar (Pinto et al., 2009). In the late 1980s and early 1990s, mango crop has expanded to other areas of northeastern Brazil driven by internal demand and by the rising interest of international markets. Approximately 1,870 hectares were planted in the north of Piauí State, in Northeast Brazil, and, as in the São Francisco river valley, the cultivar Tommy

Pesq. agropec. bras., Brasília, v.47, n.1, p.36-43, jan. 2012 
Atkins dominated the orchards, corresponding to $80 \%$ of the trees.

The success of 'Tommy Atkins' mango in northeastern Brazil was restricted to the semiarid areas, due to the serious problems reported in areas with higher rainfall and temperatures. In the north of Piauí, after the initial euphoria, growers soon realized the obstacles in the adaptation process of this mango cultivar to the local growth conditions, especially excessive vegetative growth, inadequate nutrition management, poor flowering, lack of management for training and proper planting spacing. These problems resulted in low fruit yield and, together with market issues, were decisive for the failure of the activity.

According to the literature, some of these problems can be expected when the Tommy Atkins cultivar is subjected to humid tropical growing conditions (Kulkarni \& Hamilton, 1997; Campbell \& Wasielewsky, 2000; Ramírez \& Davenport, 2010). Agricultural research institutions in the region have been seeking for alternatives to avoid these problems. Among the research studies in progress, breeding programs, improvement of the floral induction process, canopy replacement with well adapted and more productive varieties and higher planting density are the most promising ones.

High planting density is a technique that has been widely used in mango orchards worldwide to increase earliness (higher yield per area at the first and second years), to improve handling and cultural practices, and to reduce costs (Iyer \& Kurian, 1992; Nath et al., 2007; Oosthuyse, 2009). In mango orchards, some studies support the use of this technology in different countries, with fruit yield reaching around $20 \mathrm{Mg} \mathrm{ha}^{-1}$ per year in the third harvest (Ram \& Sirohi, 1991; Oosthuyse, 2009). This value is almost three times higher than the world mean yield (Fivaz \& Stassen, 1997; Nath et al., 2007). The trend of increasing planting density is also observed in Brazil, due to increases in agricultural land cost. In addition, the incorporation of new areas to the production process is hindered by legal, economic and environmental restrictions.

Plant response to planting density depends on intrinsic variables related to the plants themselves, such as rootstock, vigor, canopy age and extrinsic variables, including soil and climate (Policarpo et al., 2006; Yamakura et al., 2008). Consequently, studies on planting density in mango should be carried out in each producing region.

The objective of this work was to evaluate the effects of high density planting on 'Tommy Atkins' mango trees cultivated in subhumid warm tropical climate in northeastern Brazil.

\section{Materials and Methods}

Field research was carried out at experimental station of Embrapa Meio-Norte, in Teresina, PI, Brazil $\left(5^{\circ} 01^{\prime} 52^{\prime \prime} \mathrm{S}\right.$ and $42^{\circ} 48^{\prime} 01^{\prime \prime} \mathrm{W}$, at $77 \mathrm{~m}$ above sea level), in 2007 and 2008. The local climate is classified as Aw, according to Köppen-Geiger, with mean annual rainfall of 1,324 mm, from January to April. Average annual relative humidity was $72.7 \%$, and average maximum and minimum air temperatures were $33.8^{\circ} \mathrm{C}$ and $23.1^{\circ} \mathrm{C}$, respectively. The soil of the area is classified as Argissolo Vermelho-amarelo (Ultisol) (Santos et al., 2006), with sandy loam texture and slightly undulated topography.

Mango orchard was established in 2000 by planting one-year-old 'Tommy Atkins' trees, which were grafted on a rustic and adapted important local mango rootstock, known as 'Fiapo'. Young mango trees were trained according to Campbell \& Wasielewski (2000). Three or four lower scaffold limbs were allowed to develop evenly spaced in a $360^{\circ}$ horizontal plane. Trees were regularly trained at the first three years to obtain an open cup shape. Then, annual canopy thinning was performed to maintain tree shape and height control. Mango trees remained healthy during the experimental period, i.e., there were no pests or diseases that required control measures.

Plants were transplanted to the field in five spacial arrangements, considering the distance between plant rows and between plants into the rows $(8 \times 5 \mathrm{~m}, 7 \times 4$ $\mathrm{m}, 6 \times 3 \mathrm{~m}, 5 \times 2 \mathrm{~m}$ and $4 \times 2 \mathrm{~m}$ ), which corresponded to five planting densities: 250 (traditional/control), 357, 555, 1,000 and 1,250 plants per hectare, respectively. The experimental design was a randomized complete block with four replicates. The plot consisted of 3, 4, 7, 12 and 15 useful plants for planting densities of 250 , $357,555,1,000$ and 1,250 plants per hectare, respectively. Each plot measured approximately $120 \mathrm{~m}^{2}$.

Plants were prepared to start producing fruit in 2007. Therefore, in January 2007, at the rainy season 
onset, plants were subjected to canopy pruning. All the plants had the lower branches removed. The plants grown under planting densities of 250 and 357 plants per hectare also had the last two growth flushes removed. Under higher planting densities $(555,1,000$ and 1,250 plants per hectare), several branches grew up vertically. Therefore, a more drastic pruning was performed, completely eliminating these branches. In late January 2008, after fruits were harvested, post-harvest pruning was performed by removing the branches that grew near to the ground and those that grew up vertically, and by cutting just one growth flush in the lateral branches.

Orchard fertilization management was carried out according to soil and leaf analysis, which was interpreted according to Souza et al. (1999) and Silva et al. (2002). Before the first fruit yield, in mid-April 2007, $1.2 \mathrm{Mg} \mathrm{ha}^{-1}$ of lime (effective calcium carbonate $\mathrm{CC}=100 \%$ ) was incorporated to the soil in order to increase basis saturation ( $\mathrm{V} \%$ ) to $80 \%$, and $50 \mathrm{~g}$ of boric acid per plant were applied in the soil surrounding the plants. In early November 2007, gypsum $(1.5 \mathrm{~kg}$ per plant) and boric acid (50 g per plant) were also applied. At the end of April 2008, the following amounts of fertilizer per plant were applied: $750 \mathrm{~g}$ of superphosphate, $100 \mathrm{~g}$ of potassium chloride and $80 \mathrm{~g}$ of FTE (fritted trace elements, a source of micronutrients). In early August 2008, $200 \mathrm{~g}$ of potassium chloride and $150 \mathrm{~g}$ per plant of boric acid were applied.

Water was applied by sprinkler irrigation from flowering to fruit physiological maturity, between September and December. The system operated with one sprinkler per plant which was installed $30 \mathrm{~cm}$ away from the trunk, with a water discharge rate of $70 \mathrm{~L} \mathrm{~h}^{-1}$. Irrigation management was performed according to the reference evapotranspiration (ETo), taking as base 100\% of the evaporation rate from a Class A evaporation pan $(\mathrm{Kc}=1.0)$, according to Silva et al. (2009), with an irrigation interval of two days.

In 2007 and 2008, soon after the emission of the second growth flush after pruning, the floral induction process was started in April with the application of paclobutrazol (PBZ) in a single dose of $1.0 \mathrm{~g}$ of active ingredient per meter of canopy diameter, $50 \mathrm{~cm}$ away from the trunk base. Bud sprouting was induced by foliar application of three sprays of $\mathrm{KNO}_{3}$ at $4 \%$ concentration, on a seven-day interval, starting at 100 days after PBZ application (early August). Just before the first application of $\mathrm{KNO}_{3}$, pre-floral pruning was performed, which consisted of removing vegetative immature shoots, besides early flowers and fruits. Flowering and fruiting occurred in late August and early September, respectively, and mango fruits were harvested in December.

The following vegetative variables were evaluated: plant height, trunk diameter $10 \mathrm{~cm}$ above and $10 \mathrm{~cm}$ below the grafting point, canopy diameter into the row and between rows, canopy height, number and length of terminal shoots and number of compressed apical shoots. All of these variables were measured in 2007 and 2008, with the exception of the last three, which were measured only in 2007 - up to a height of $2 \mathrm{~m}$ above ground -, and of canopy height, which was measured only in 2008. Among the reproductive variables, number and percentage of flowering shoots, number of fruit per plant and fruit yield were evaluated only in 2007, since flowering and fruiting were insignificant in 2008, indicating irregular bearing of 'Tommy Atkins' mango trees in the region.

All fruits were harvested in mid-December, and ten fruits from each plot were randomly sampled. A subsample of four ripened fruits was taken for laboratory analysis, according to Yeshitela et al. (2003). Analysis consisted on determination of fruit and pulp weight, fruit length, dorsal and ventral fruit diameter, pulp firmness, soluble solids ( ${ }^{\circ}$ Brix), titratable acidity and $\mathrm{pH}$. These variables were determined in the 2008 harvest.

Prior to statistical analysis, tests were performed in order to verify whether all data set showed homogeneity of variance and normal distribution of errors. For data sets that did not meet this precondition, the most appropriated data transformation was performed after the procedure described by Montgomery (1991). Therefore, for variables, such as vegetative shoots $(\%)$, flowering shoots $(\%)$, compressed shoots (\%) and shoots that have not sprouted (\%), data were transformed into arc sen $(\mathrm{x} / 100)^{0.5}$. For the number of fruits per plant, terminal and floral shoot number, values were transformed into $\mathrm{x}^{0.5}$. Subsequently, all data, transformed or not, were subjected to analysis of variance according to Snedecor \& Cochran (1967). Statistical analysis was carried out using the available area per plant in every planting density. Therefore, 40 , $28,18,10$ and $8 \mathrm{~m}^{2}$ per plant correspond to 250,357 , $555,1,000$ and 1,250 plants per hectare, respectively. 
After analysis of variance, a regression equation was adjusted for significantly different averages, using the GLM procedure (SAS Institute, 2002).

\section{Results and Discussion}

Vegetative variables of 'Tommy Atkins' mango trees showed significant changes in response to higher planting density. In general, plants grown under traditional wide spacing $(8 \times 5 \mathrm{~m}=40$ square meter per tree) showed greater vegetative growth than those grown
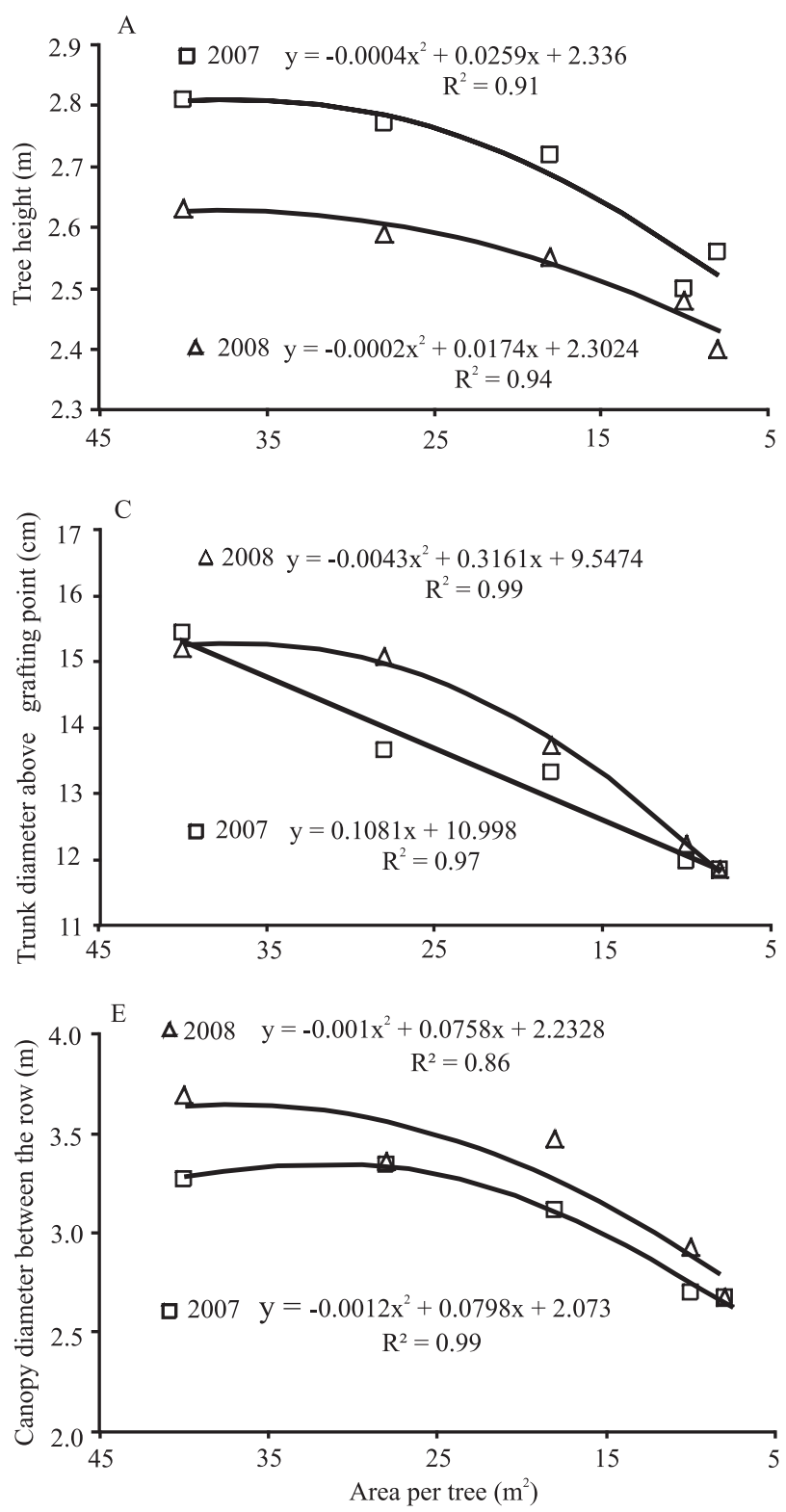

under narrow spacing. As the area for each plant was decreased, there was a decrease in plant height, trunk diameter below and above the grafting point, diameter of the canopy into the row and between rows, canopy height (Figure $1 \mathrm{~A}$ to F), number and length of terminal shoots (Figure $2 \mathrm{~A}$ and B). However, an increase was also observed in the percentage of compressed and not sprouting shoots (Figure $2 \mathrm{C}$ ).

The reduction in vegetative variables in 'Tommy Atkins' mango trees grown under increased planting density had already been observed in other studies
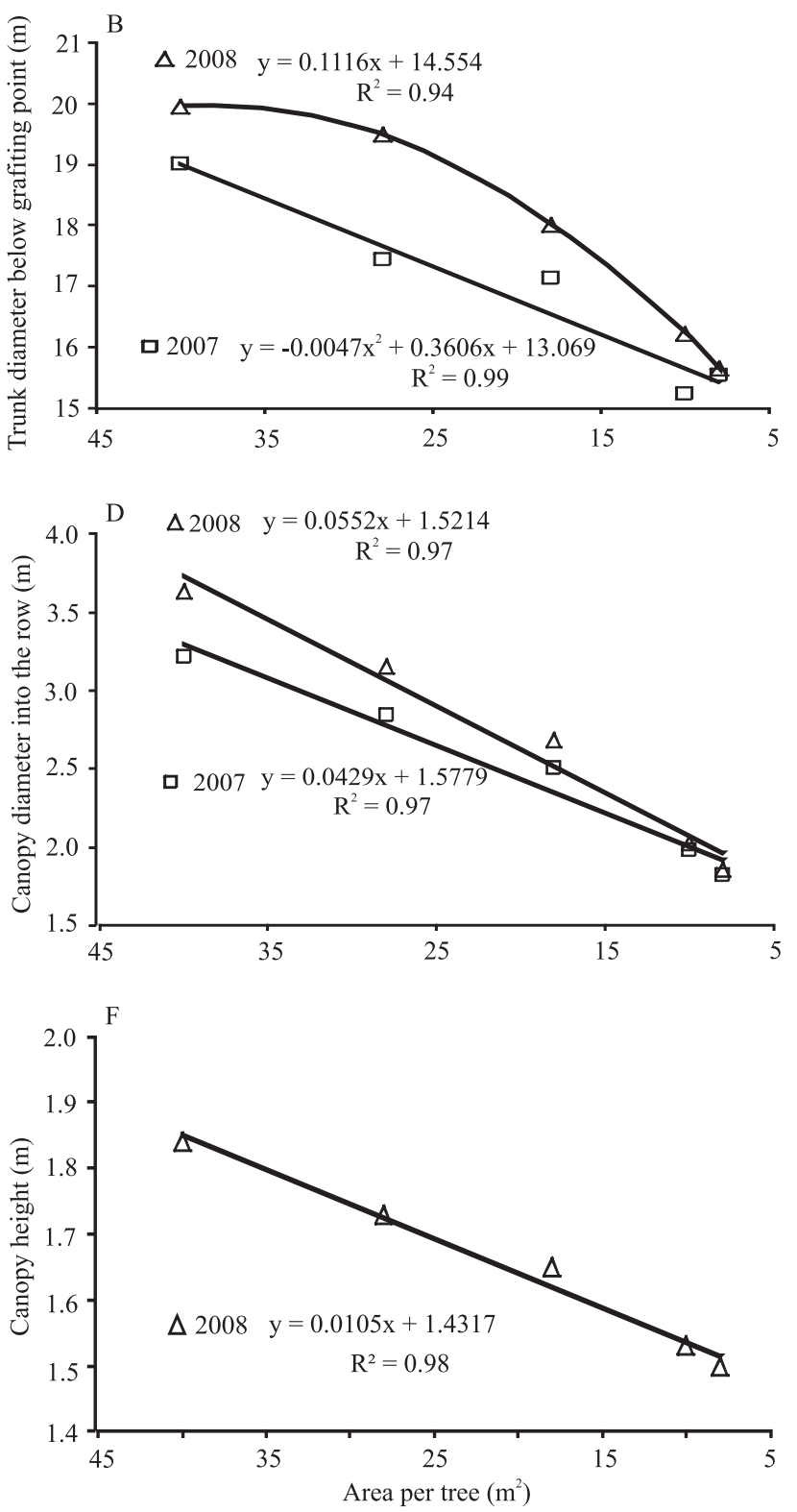

Figure 1. Vegetative variables of 'Tommy Atkins' mango trees grown at increasing planting densities in subhumid warm tropical climate in northeastern Brazil. 
with other mango cultivars (Ram \& Sirohi 1991; Nath et al., 2007) and with other fruit species, such as pear (Policarpo et al., 2006), guava (Singh et al., 2007) and fig (Yamakura et al., 2008). A possible explanation is the competition for water and soil nutrients (Policarpo et al., 2006), but mainly for light (Johnson \& Robinson, 2000; Policarpo et al., 2006), since under higher planting density plant canopies overlap into the rows, reducing light incidence on leaves. Consequently,
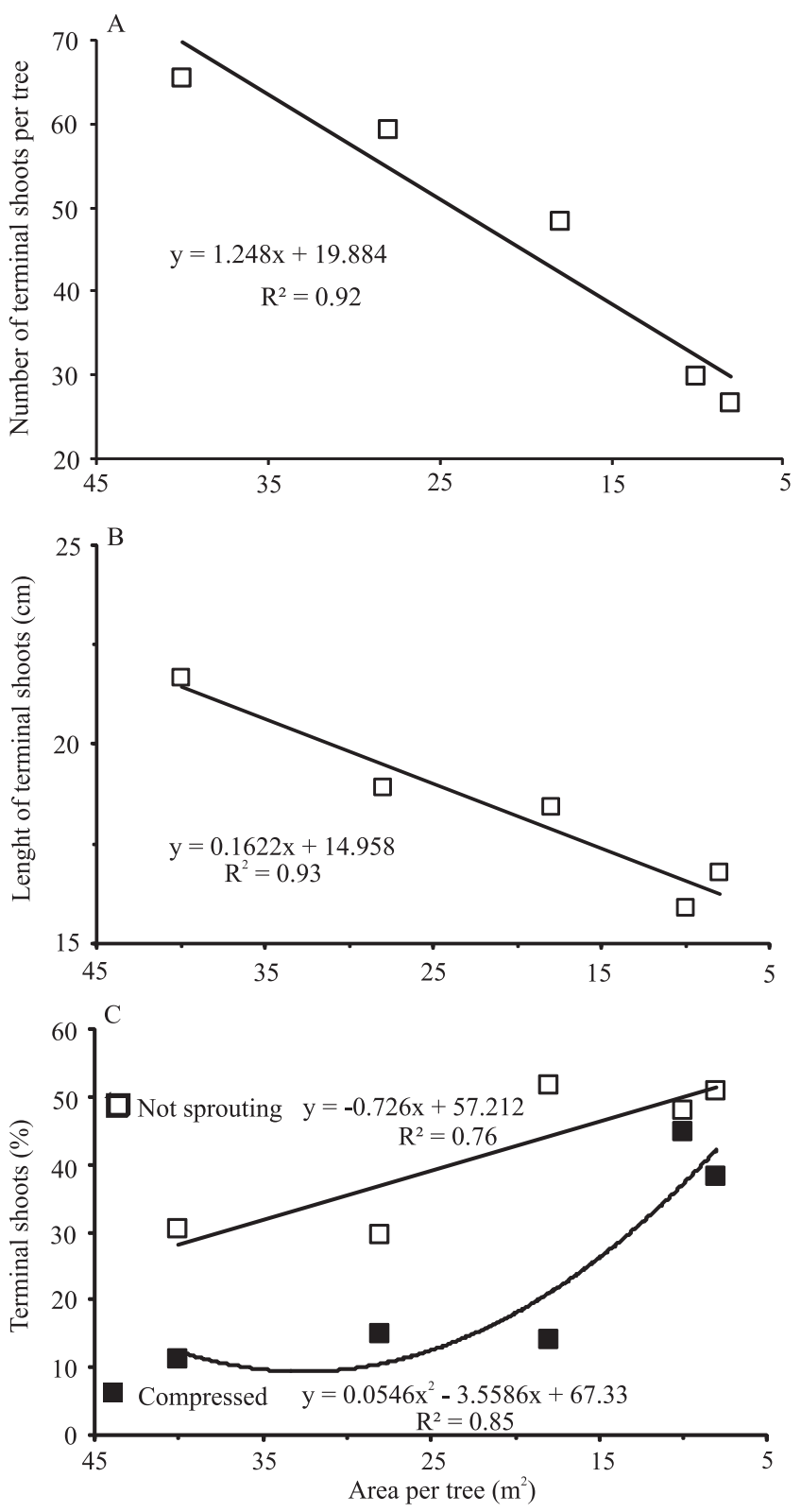

Figure 2. Terminal shoots variables of 'Tommy Atkins' mango trees grown at increasing planting densities in subhumid warm tropical climate in northeastern Brazil. great part of the canopy contributes little or nothing to the synthesis of carbohydrates necessary for growth.

Differently from other variables, such as trunk diameter, which confirmed the trend of reduced growth under high planting density, in virtually all studies (Nath et al., 2007; Singh et al., 2007; Yakamura et al., 2008), plant height can decrease, as occurred with 'Dashehari' mango (Ram \& Sirohi, 1991), or increase, as observed by Nath et al. (2007), while evaluating 'Amrapali' mango. Therefore, the effect of planting density on that trait seems to be variable. However, the way that the plants are trained is also important, which may accentuate or not apical dominance and, consequently, height growth as planting density increases. In higher planting densities, canopy diameter between rows showed less reduction than canopy diameter into the rows. This probably occurred because the former were not overlapping and, therefore, were not subject to the restrictions of light, unlike what occurred with the latter.

Reduced mango tree growth under high planting density was to some extent an expected result (Ram \& Sirohi, 1991; Nath et al., 2007) and apparently is not a problem per se. Data for plant height and canopy diameter, although consistent, may have been masked by pruning performed in previous years. In any case, smaller plants with high apical dominance tend to have less terminal shoots, as observed in the present study, in accordance to Johnson \& Robinson (2000). Other interesting results were the decrease in shoot length and the increase in the percentage of compressed and not sprouting shoots, due to increased planting density. It is possible that PBZ had a negative effect on plants grown under higher planting densities. Since the PBZ dose was calculated based only on the canopy diameter, it may have been excessive for plants at higher planting densities, which showed lower canopy height and, consequently, lower canopy volume.

In general, plants showed a low percentage of flowering and, subsequently, low fruit yield, indicating some of the problems that a vigorous mango tree cultivar, such as Tommy Atkins, may have on the warm tropics (Ramírez \& Davenport, 2010). As with vegetative variables, reproductive variables were also negatively affected by planting density (Figure 3 ). The smaller the area available to plants, the higher the tendency to decrease the number and percentage of 
flower shoots, and the number and yield of fruit per plant.

A consequence of the higher planting densities was the reduction of the number and percentage of flowering shoots. Plants grown under lower planting density produced flowers in all quadrants of the canopy, while those grown under increasing planting density (555, 1,000 and 1,250 plants per hectare) produced flowers only in the two quadrants of the canopy between the rows, but not into the rows. Consequently, there were reductions in the number and yield of fruits per plant. In the planting densities of 555, 1,000 and 1,250 plants per hectare, the number of fruits produced represented only about $1 / 4$ of those produced in the lowest planting density, with 250 plants per hectare. However, the planting densities of 250 and 357 plants per hectare showed little difference in relation to the number and yield of fruit per plant. Planting density of 357 plants per hectare showed estimated fruit yield of $8.78 \mathrm{Mg} \mathrm{ha}^{-1}$ per year, representing an increase of approximately $30 \%$ compared to the fruit yield obtained at the planting density of 250 plants per hectare, which was $6.65 \mathrm{Mg} \mathrm{ha}^{-1}$ per year.
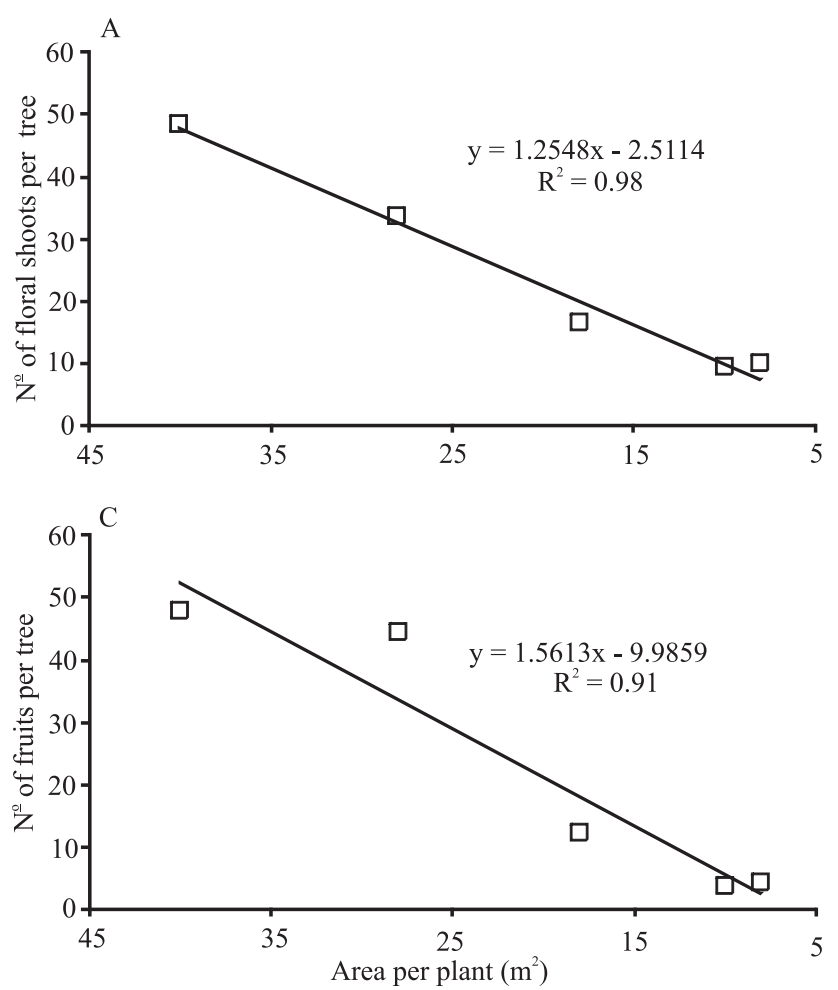

The fruit yield obtained in the present study, at least for the two spacings in which plants were grown under lower planting densities, is consistent with the performance of vigorous North-American mango cultivars under subhumid warm tropical conditions (Johnson \& Robinson, 2000). Furthermore, the fruit yield obtained is close to the world mean fruit yield for mango, which is $7.5 \mathrm{Mg} \mathrm{ha}^{-1}$ per year (Malik \& Singh, 2006), being higher than the fruit yield of about $5 \mathrm{Mg} \mathrm{ha}^{-1}$ reported by Blaikie et al. (2004) in a region of Australia which has similar climatic conditions to the one where the present study was implemented. However, the results found are far below the fruit yield obtained in other regions with favorable climate conditions, in which mango trees were grown under high plant density (Oosthuyse, 1994).

Increasing planting density did not change significantly most variables related to fruit quality, such as fruit and pulp weight, fruit length, dorsal fruit diameter, soluble solids ( ${ }^{\circ}$ Brix), titratable acidity and $\mathrm{pH}$. Only fruit ventral diameter and pulp firmness were significantly different. Therefore, in the present study, high planting density had little influence on
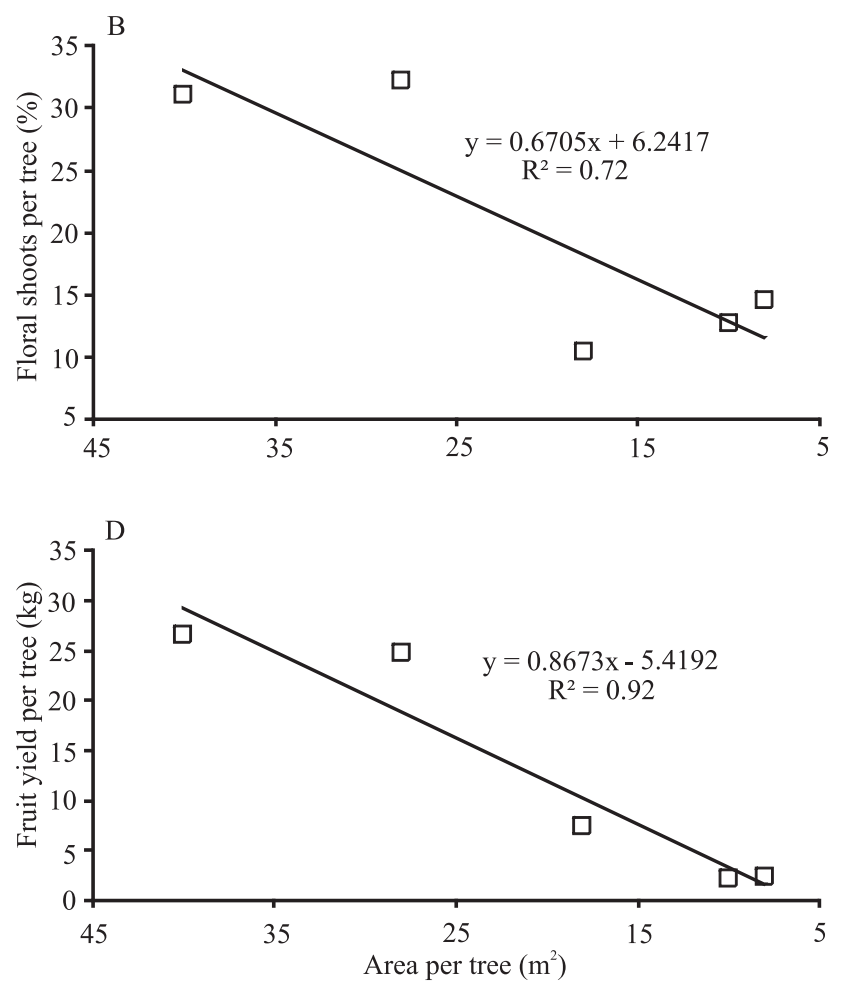

Figure 3. Reproductive variables of 'Tommy Atkins' mango trees grown at increasing planting densities in subhumid warm tropical climate in northeastern Brazil. 
fruit quality, as reported in other studies with mango (Ram \& Sirohi, 1991; Nath et al., 2007). However, there was a decrease in the fruit ventral diameter and an increase in pulp firmness, as plants were exposed to increasing planting density (Figure 4). The decrease in fruit ventral diameter, together with no changes in fruit weight, fruit pulp weight or fruit length, indicates that fruits become thinner, more compacted and, therefore, show increased pulp firmness.

According to Policarpo et al. (2006), under high planting density, besides the changes in the quantity and quality of intercepted light, the partitioning of assimilates between vegetative and reproductive shoots may be responsible for the effects on fruit quality. However, in the literature on the effect of high planting density on fruit quality in several plants, the results are not as consistent as those obtained for plant growth or fruit yield. There are studies in which fruit quality was maintained (Ram \& Sirohi, 1991), suffered little (Nath et al., 2007) or considerable changes (Moreira et al., 2007; Singh et al., 2007; Souza et al., 2009). In the latter, fruit weight is among
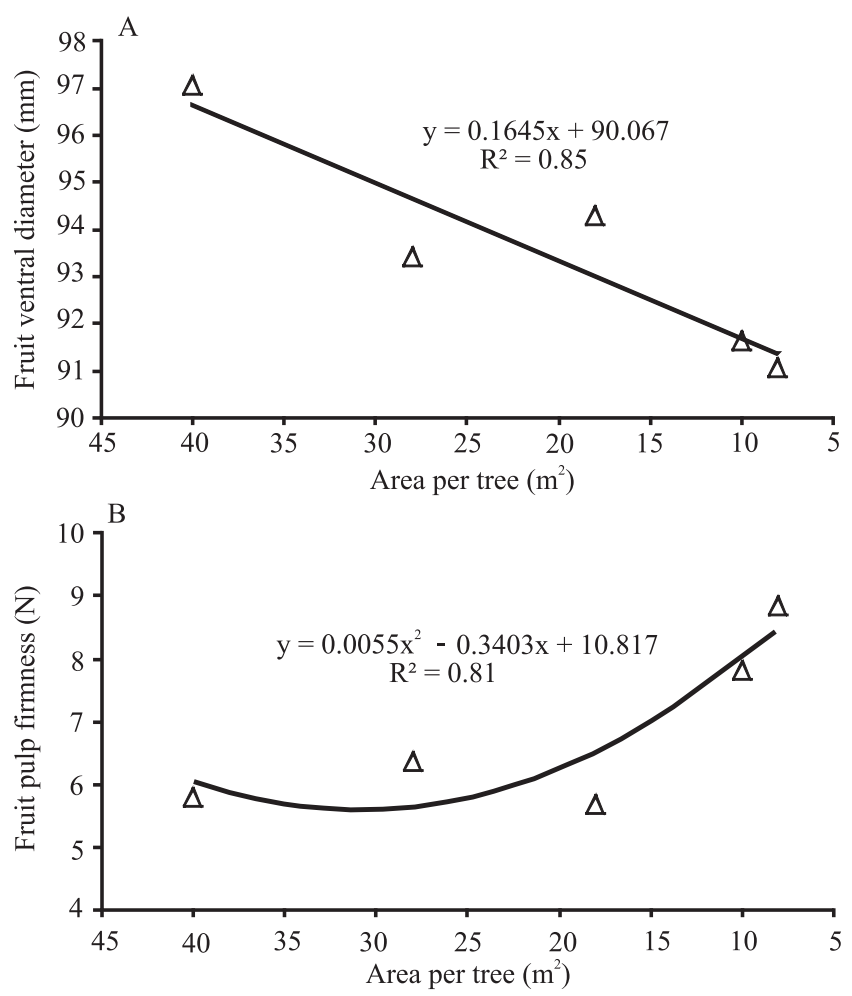

Figure 4. Fruit quality of 'Tommy Atkins' mango trees grown at increasing planting densities in subhumid warm tropical climate in northeastern Brazil. the variables that changed more often due to high planting density (Policarpo et al., 2006; Singh et al., 2007; Souza et al., 2009).

\section{Conclusions}

1. Increasing planting density in 'Tommy Atkins' mango in subhumid climate until 357 plants per hectare $(7 \times 4 \mathrm{~m})$ increases fruit yield per area by approximately $30 \%$ in comparison to the traditional planting density, with 250 plants per hectare $(8 \times 5 \mathrm{~m})$.

2. Above 555 plants per hectare $(6 \times 3 \mathrm{~m})$, plant growth, percentage of flowering, fruit yield per plant and fruit yield per area decrease, but with little effect on fruit quality.

\section{Acknowledgements}

To Banco do Nordeste do Brasil, for financial support; to Coordenação de Aperfeiçoamento de Pessoal de Nível Superior, for scholarship granted; to Erisvaldo Bispo Cardoso, for technical assistance.

\section{References}

ANUÁRIO brasileiro da fruticultura. Santa Cruz do Sul: Gazeta Santa Cruz, 2011. 128p.

BLAIKIE, S.J.; KULKARNI, V.J.; MÜLLER, W.J. Effects of morphactin and paclobutrazol flowering treatments on shoot and root phenology in mango cv. Kensington Pride. Scientia Horticulturae, v.101, p.51-68, 2004.

CAMPBELL, R.J.; WASIELEWSKI, J. Mango tree training techniques for the hot tropics. Acta Horticulturae, n.509, p.641-652, 2000.

FIVAZ, J.; STASSEN, P.J.C. The role of training systems in maintaining higher density mango orchards. Acta Horticulturae, n.455, p.407-412, 1997.

INSTITUTO BRASILEIRO DE GEOGRAFIA E ESTATÍSTICA. SIDRA: banco de dados agregados: Tabela 1613. Disponível em: <http://www.sidra.ibge.gov.br/bda/tabela/listabl. asp? $=1613 \& z=t \& o=11>$. Acesso em: 3 out. 2011.

IYER, C.P.A.; KURIAN, R.M. Tree size control in mango (Mangifera indica L.) - some considerations. Acta Horticulturae, n.321, p.425-436, 1992.

JOHNSON, P.R.; ROBINSON, D.M. The tatura trellis system for high density mangoes. Acta Horticulturae, n.509, p.359-364, 2000 .

KULKARNI, V.; HAMILTON, D. An integrated approach towards improving mango productivity. Acta Horticulturae, n.455, p.84-91, 1997. 
MALIK, A.U.; SINGH, Z. Improved fruit retention, yield and fruit quality in mango with exogenous application of polyamines. Scientia Horticulturae, v.110, p.167-174, 2006.

MONTGOMERY, D.C. Design and analysis of experiments. $3^{\text {rd }}$ ed. New York: John Wiley and Sons, 1991. 649p.

MOREIRA, A.; HEINRICHS, R.; PEREIRA, J.C.R. Densidade de plantio na produtividade e nos teores de nutrientes nas folhas e frutos da bananeira cv. Thap Maeo. Revista Brasileira de Fruticultura, v.29, p.626-631, 2007.

NATH, V.; DAS, B.; RAI, M. Standardization of high-density planting in mango (Mangifera indica) under sub-humid Alfisols of Eastern India. Indian Journal of Agricultural Sciences, v.77, p.3-7, 2007.

OOSTHUYSE, S.A. Management of a 'Tommy Atkins', ultra-high density orchard and recognized benefits associated with small tree mango orchards. Acta Horticulturae, n.820, p.335-338, 2009.

OOSTHUYSE, S.A. Pruning for sensation mango trees to maintain their size and effect uniform and later flowering. South African Mango Grower Association Yearbook, v.14, p.1-5, 1994.

PINTO, A.C. de Q.; FALEIRO, F.G.; RAMOS, V.H.V.; CORDEIRO, M.C.R.; ANDRADE, S.R.M. de; JUNQUEIRA, N.T.V.; DIAS, J.N. Performance of seven new mango (Mangifera indica L.) hybrid selections at the central region of Brazil. Acta Horticulturae, n.820, p.137-146, 2009.

POLICARPO, M.; TALLUTO, G.; BIANCO R.L. Vegetative and productive responses of 'Conference' and 'Williams' pear trees planted at different in-row spacings. Scientia Horticulturae, v.109, p.322-331, 2006.

RAM, S.; SIROHI, S.C. Feasibility of high density orcharding in Dashehari mango. Acta Horticulturae, n.291, p.207-212, 1991.

RAMÍREZ, F.; DAVENPORT, T.L. Mango (Mangifera indica L.) flowering physiology. Scientia Horticulturae, v.126, p.65-72, 2010.

SANTOS, H.G. dos; JACOMINE, P.K.T.; ANJOS, L.H.C. dos; OLIVEIRA, V.A. de; OLIVEIRA, J.B. de; COELHO, M.R.;
LUMBRERAS, J.F.; CUNHA, T.J.F. (Ed.). Sistema brasileiro de classificação de solos. 2.ed. Rio de Janeiro: Embrapa Solos, 2006. $306 \mathrm{p}$.

SAS INSTITUTE. SAS/STAT: user's guide. Version 8.1. Cary: SAS Institute, 2002. 943p.

SILVA, D.J.; QUAGGIO, J.A.; PINTO, P.A. da C.; PINTO, A.C. de Q.; MAGALHÃES, A.F. de J. Nutrição e Adubação. In: GENÚ, P.J. de C.; PINTO, A.C. de Q. (Ed.). A cultura da mangueira. Brasília: Embrapa Informação Tecnológica, 2002. p.191-221.

SILVA, V. de P.R. da; CAMPOS, J.H.B. da C.; AZEVEDO, P.V. de. Water-use efficiency and evapotranspiration of mango orchard grown in northeastern region of Brazil. Scientia Horticulturae, v.120, p.467-472, 2009.

SINGH, G.; SINGH, A.K.; MISHRA, D. High density planting in guava. Acta Horticulturae, n.735, p.235-241, 2007.

SNEDECOR, G.W.; COCHRAN, W.G. Statistical methods. $6^{\text {th }}$ ed. Ames: Iowa State University, 1967. 593p.

SOUZA, O.P. de; TEODORO, R.E.F.; MELO, B. de; TORRES, J.L.R. Qualidade do fruto e produtividade do abacaxizeiro em diferentes densidades de plantio e lâminas de irrigação. Pesquisa Agropecuária Brasileira, v.44, p.471-477, 2009.

SOUZA, M. de; GUIMARÃES, P.T.G.; CARVALHO, J.G. de C.; FRAGOAS, J.C. Mangueira. In: RIBEIRO, A.C.; GUIMARÃES, P.T.G.; ALVAREZ V., V.H. (Ed.). Recomendações para uso de corretivos e fertilizantes em Minas Gerais: 5a aproximação. Viçosa: Comissão de Fertilidade do Solo do Estado de Minas Gerais, 1999. 359p.

YAMAKURA, T.; HOSOMI, A.; HIRAYAMA, D. Effect of tree spacing on vegetative growth and reproduction in an early growth stage in two cultivars of Ficus carica L. Journal of the Japanese Society for Horticultural Science, v.77, p.7-16, 2008.

YESHITELA, T.; ROBBERTSE, P.J.; STASSEN, P.J.C. The impact of panicle and shoot pruning on inflorescence and yield related developments in some mango cultivars. Journal of Applied Horticulture, v.5, 69-75, 2003.

Received on May 3, 2011 and accepted on November 25, 2011 